\title{
Front Matter: Volume 7030
}

, "Front Matter: Volume 7030," Proc. SPIE 7030, Nanophotonic Materials V, 703001 (3 October 2008); doi: 10.1117/12.806018

SPIE Event: NanoScience + Engineering, 2008, San Diego, California, United SPIE. States 


\title{
PROCEEDINGS OF SPIE
}

\section{Nanophotonic Materials V}

\author{
Zeno Gaburro \\ Stefano Cabrini \\ Dmitri Talapin \\ Editors \\ 10-12 August 2008 \\ San Diego, California, USA \\ Sponsored and Published by \\ SPIE
}

Volume 7030 
The papers included in this volume were part of the technical conference cited on the cover and title page. Papers were selected and subject to review by the editors and conference program committee. Some conference presentations may not be available for publication. The papers published in these proceedings reflect the work and thoughts of the authors and are published herein as submitted. The publisher is not responsible for the validity of the information or for any outcomes resulting from reliance thereon.

Please use the following format to cite material from this book:

Author(s), "Title of Paper," in Nanophotonic Materials V, edited by Zeno Gaburro, Stefano Cabrini, Dmitri Talapin, Proceedings of SPIE Vol. 7030 (SPIE, Bellingham, WA, 2008) Article CID Number.

ISSN 0277-786X

ISBN 9780819472502

Published by

SPIE

P.O. Box 10, Bellingham, Washington 98227-0010 USA

Telephone +1 3606763290 (Pacific Time) · Fax +1 3606471445

SPIE.org

Copyright (C) 2008, Society of Photo-Optical Instrumentation Engineers

Copying of material in this book for internal or personal use, or for the internal or personal use of specific clients, beyond the fair use provisions granted by the U.S. Copyright Law is authorized by SPIE subject to payment of copying fees. The Transactional Reporting Service base fee for this volume is $\$ 18.00$ per article (or portion thereof), which should be paid directly to the Copyright Clearance Center (CCC), 222 Rosewood Drive, Danvers, MA 01923. Payment may also be made electronically through CCC Online at copyright.com. Other copying for republication, resale, advertising or promotion, or any form of systematic or multiple reproduction of any material in this book is prohibited except with permission in writing from the publisher. The CCC fee code is 0277-786X/08/\$18.00.

Printed in the United States of America.

Publication of record for individual papers is online in the SPIE Digital Library.

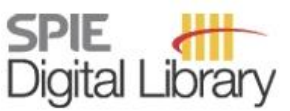

SPIEDigitalLibrary.org

Paper Numbering: Proceedings of SPIE follow an e-First publication model, with papers published first online and then in print and on CD-ROM. Papers are published as they are submitted and meet publication criteria. A unique, consistent, permanent citation identifier (CID) number is assigned to each article at the time of the first publication. Utilization of CIDs allows articles to be fully citable as soon they are published online, and connects the same identifier to all online, print, and electronic versions of the publication. SPIE uses a six-digit CID article numbering system in which:

- The first four digits correspond to the SPIE volume number.

- The last two digits indicate publication order within the volume using a Base 36 numbering system employing both numerals and letters. These two-number sets start with $00,01,02,03,04$, $05,06,07,08,09,0 A, 0 B \ldots 0 Z$, followed by 10-1Z, 20-2Z, etc.

The CID number appears on each page of the manuscript. The complete citation is used on the first page, and an abbreviated version on subsequent pages. Numbers in the index correspond to the last two digits of the six-digit CID number. 


\section{Contents}

vii Conference Committee

ix Revivals of molecular nonlinear optics in physics, chemistry, and life sciences (Plenary Paper) [7040-100]

J. Zyss, Lab. de Photonique Quantique et Moléculaire, CNRS, Institut d'Alembert (France)

\section{SESSION 1 SYNTHESIS AND FABRICATION I}

703002 Novel hybrid nanostructures for photonic and energy applications (Invited Paper) [7030-01] S. E. Habas, T. Mokari, Lawrence Berkeley National Lab. (United States)

703003 Ge nanoparticles growth in Ge-doped sol-gel silica by e-beam exposure [7030-02] N. Chiodini, R. Lorenzi, A. Lauria, G. Spinolo, A. Paleari, Univ. of Milano-Bicocca (Italy)

703004 Strong photoluminescence at $1540 \mathrm{~nm}$ from Er-doped amorphous silicon oxycarbide: a novel silicon material for photonic applications [7030-03]

S. Gallis, V. Nikas, H. Suhag, M. Huang, A. E. Kaloyeros, Univ. at Albany, SUNY (United States)

\section{SESSION 2 CHARACTERIZATION I}

703007 Synthesis of $\mathrm{Y}_{2} \mathrm{O}_{3}-\mathrm{MgO}$ nanopowder and infrared transmission of the sintered nanocomposite [7030-07]

D. Jiang, A. K. Mukherjee, Univ. of California, Davis (United States)

\section{SESSION 3 SYNTHESIS AND FABRICATION II}

7030 OE Frequency selective surfaces offer new possibilities as reflectance filters in the NIR/visible spectrum [7030-14]

G. F. Walsh, R. M. Osgood III, D. Ziegler, U.S. Army Natick Soldier Research Development and Engineering Ctr. (United States); M. Roy, U.S. Army Reseach Lab. (United States); J. Carlson, L. Belton, B. R. Kimball, U.S. Army Natick Soldier Research Development and Engineering Ctr. (United States)

7030 OF The role of nanoparticles in visible transparent nanocomposites [7030-15]

T. Druffel, O. Buazza, M. Lattis, S. Farmer, M. Spencer, Optical Dynamics (United States);

N. Mandzy, E. A. Grulke, Univ. of Kentucky (United States) 
7030 Ol Simple silanization routes of CdSe and CdTe nanocrystals for biological applications [7030-19]

D. B. Almeida, W. M. Faustino, G. J. Jacob, A. A. de Thomaz, L. C. Barbosa, O. L. Alves, Univ. Estadual de Campinas (Brazil); P. M. A. Farias, B. S. Santos, A. Fontes, Univ. Federal de Pernambuco (Brazil); S. A. O. Gomes, Fundacao Oswaldo Cruz (Brazil); D. Feder, Univ. Federal Fluminense (Brazil); I. O. Mazali, C. L. Cesar, Univ. Estadual de Campinas (Brazil)

\section{SESSION 5 APPLICATIONS II}

$70300 \mathrm{M}$ Design and optimization of plasmonic-based metal-dielectric nanocomposite materials for energy applications [7030-21]

J. Trice, C. Favazza, R. Sureshkumar, Washington Univ. in St. Louis (United States); H. Garcia, Southern Illinois Univ. (United States); R. Kalyanaraman, Univ. of Tennessee (United States)

\section{SESSION 6 CHARACTERIZATION II}

7030 OS Stimulated emission depletion and fluorescence correlation spectroscopy of a branched quadrupolar chromophore [7030-27]

D. A. Armoogum, R. J. Marsh, N. Nicolaou, Univ. College London (United Kingdom); O. Mongin, M. Blanchard-Desce, Synthèse of ElectroSynthèse Organiques, CNRS, Univ. de Rennes I (France); A. J. Bain, Univ. College London (United Kingdom)

7030 OT Adsorption of mercaptosilanes on nanocrystalline and single crystal zinc oxide surfaces [7030-28]

J. Singh, J. Im, J. E. Whitten, Univ. of Massachusetts Lowell (United States); J. W. Soares, A. M. Meehan, D. M. Steeves, U.S. Army Natick Soldier Research, Development and Engineering Ctr. (United States)

$7030 \mathrm{OU}$ The Finite Element Method as applied to the calculation of the quantum efficiency in optoelectronic imaging devices [7030-29]

G. Demésy, Institut Fresnel, Univ. Aix-Marseill III, École Centrale de Marseille (France) and STMicroelectronics (France); F. Zolla, A. Nicolet, M. Commandré, C. Fossati, Institut Fresnel, Univ. Aix-Marseill III, École Centrale de Marseille (France); S. Ricq, O. Gagliano, B. Dunne, STMicroelectronics (France)

\section{POSTER SESSION}

$7030 \mathrm{OZ}$ Tuning the absorption and emission of CdSe and ZnS core-shell nanoparticles by laser radiation [7030-36]

I. F. Gallardo, K. Hoffmann, J. Keto, The Univ. of Texas at Austin (United States)

$703010 \quad$ Ultraviolet cross-link process using spin-coating materials for advanced planarization and sublimate defect reduction [7030-37]

S. Takei, Nissan Chemical Industries, Ltd. (Japan); M. Muramatsu, Tokyo Electron Kyushu, Ltd. (Japan); Y. Horiguchi, T. Ohashi, Y. Nakajima, Y. Mano, Nissan Chemical Industries, Ltd. (Japan); M. Iwashita, Tokyo Electron Kyushu, Ltd. (Japan); K. Tsuchiya, T. Yamaguchi, Tokyo Electron, Ltd. (Japan) 
703012 Multi-bubble sonoluminescence: Laboratory curiosity, or real world application? [7030-40] P. Axford, Univ. of Dundee (United Kingdom); L. Lawton, P. Robertson, Robert Gordon Univ. (United Kingdom); P. A. Campbell, Univ. of Dundee (United Kingdom)

703016 Porous oxide nanostructure with spiral staircase formed by discrete cross plastic slip [7030-45]

D. Aurongzeb, Northeastern Univ. (United States)

703017 Study on optical nonlinearities of porphyrin covalently functionalized single-wall carbon nanotubes [7030-46]

Z.-B. Liu, W.-Y. Zhou, J.-G. Tian, Z. Guo, D.-M. Ren, J.-Y. Zheng, Nankai Univ. (China)

703018 Light propagation in one-dimensional photonic finite systems $\left(\mathrm{Si} / \mathrm{a}-\mathrm{SiO}_{2}\right)_{\mathrm{m}}$ with defects [7030-47]

Y. K. Timoshenko, V. A. Shunina, Y. V. Smirnov, O. V. Kazarina, Voronezh State Univ. (Russia)

703019 Fabrication and characterisation of photonic nanowires [7030-48]

J. E. McCarthy, Á. M. Whelan, G.-L. Davies, F. Byrne, The Univ. of Dublin, Trinity College (Ireland); J. Conroy, Y. Volkov, St. James's Hospital, Dublin (Ireland); Y. Gun'ko, The Univ. of Dublin, Trinity College (Ireland)

Author Index 
Downloaded From: https://www.spiedigitallibrary.org/conference-proceedings-of-spie on 26 Apr 2023

Terms of Use: https://www.spiedigitallibrary.org/terms-of-use 


\title{
Conference Committee
}

\author{
Symposium Chairs
}

David L. Andrews, University of East Anglia Norwich (United Kingdom) James G. Grote, Air Force Research Laboratory (United States)

Kevin J. Liddane, Oerlikon Optics USA, Inc. (United States)

Conference Chairs

Zeno Gaburro, Università degli Studi di Trento (Italy)

Stefano Cabrini, Lawrence Berkeley National Laboratory

(United States)

Dmitri Talapin, University of Chicago (United States)

Program Committee

David L. Andrews, University of East Anglia Norwich (United Kingdom)

Angus J. Bain, University College London (United Kingdom)

Mireille H. Blanchard-Desce, Université de Rennes I (France)

Robert W. Boyd, University of Rochester (United States)

Aaron W. Harper, University of Southern California (United States)

Ghassan E. Jabbour, Arizona State University (United States)

Francois Kajzar, Commissariat à l'Energie Atomique (France)

Dmitri I. Kovalev, University of Bath (United Kingdom)

Paras N. Prasad, University at Buffalo (United States)

Younan Xia, University of Washington (United States)

Session Chairs

1 Synthesis and Fabrication I

Stefano Cabrini, Lawrence Berkeley National Laboratory

(United States)

2 Characterization I

Susan Habas, University of California/Berkeley (United States)

3 Synthesis and Fabrication II

John M. Lupton, The University of Utah (United States)

4 Applications I

Alexander O. Govorov, Ohio University (United States) 


\section{Applications II}

Enrico Da Como, Ludwig-Maximilians-University München (Germany)

6 Characterization II

Dmitri Talapin, University of Chicago (United States) 